DOI: https://doi.org/10.32839/2304-5809/2021-6-94-14

удК 34.340

Золотухіна Л.О., Сидоренко А.А.

Дніпропетровський державний університет внутрішніх справ

\title{
ПРАВОВЕ РЕГУЛЮВАННЯ ПРАЦІ НЕПОВНОЛІТНІХ: НАЦІОНАЛЬНИЙ ТА МІЖНАРОДНИЙ ДОСВІД
}

\begin{abstract}
Анотація. Дана стаття присвячена вивченню особливостей правового регулювання пращі неповнолітніх. Проаналізовано як національний, так і міжнародний досвід охороні праці неповнолітніх. Зауважено, що вітчизняний законодавещь чітко встановив вимоги щодо прийняття неповнолітніх на роботу, а також права неповнолітніх працівників, проте роботодавці обходять правові положення і порушують встановлені заборони. Слід враховувати, що відповідно до чинного законодавства України, неповнолітні у трудових правовідносинах прирівнюються у правах до повнолітніх, а в галузі охорони праці, робочого часу, відпусток та деяких інших умов праці користуються пільгами, встановленими законодавством України. У статті звернуто увагу і на низку проблемних питань в сфері трудової зайнятості дітей, які ще потребують вирішення. Так, недостатньо чітко регламентовано види діяльності, де дозволяється використовувати працю дітей, відсутнє визначення терміну «легка робота для неповнолітніх», неоднозначною в національному законодавстві $€$ визначення віку початку трудової діяльності для неповнолітніх, робота в якому не наносить шкоди їх здоров'ю, моралі та освіті. Констатовано, що в цілому Кодекс законів про працю України включає положення про працю неповнолітніх, статті якого відповідають нормам, прийнятим в західних країнах, стосовно можливості залучення неповнолітніх різного віку до праці різних типів важкості, відповідальності роботодавця, який заключає трудовий договір 3 неповнолітнім, та забезпечення оптимальних умов праці для неповнолітнього. Крім того, хочемо додати, що у зв'язку зі стрімким технологічним розвитком, сьогодні існуе реальна можливість зниження трудового віку дітей. Наприклад, слушним було б залучати дітей до пращі у сфері інформаційних технологій тощо. Так, у зв'язку із вказаним, вважаємо за необхідне оновлення трудового законодавства у контексті праці неповнолітніх, а саме щодо зниження віку, з якого можуть працювати діти, хоча б до 14 років.
\end{abstract}

Ключові слова: неповнолітні, праця неповнолітніх, трудові пільги для неповнолітніх, неповнолітні працівники, охорона трудових прав неповнолітніх.

Zolotukhina Lilia, Sidorenko Andrew Dnipropetrovsk State University of Internal Affairs

\section{LEGAL REGULATION OF MINORS 'WORK: NATIONAL AND INTERNATIONAL EXPERIENCE}

Summary. This article is devoted to the study of the peculiarities of the legal regulation of juvenile labor. The author analyzes both national and international experience in the protection of minors. The author notes that the domestic legislator has clearly established the requirements for the employment of minors, as well as the rights of minors, but employers circumvent the legal provisions and violate the established prohibitions. It should be borne in mind that according to the current legislation of Ukraine, minors in employment are equated in rights to adults, and in the field of labor protection, working hours, holidays and some other working conditions enjoy the benefits established by the legislation of Ukraine. The article also draws attention to a number of problematic issues in the field of employment of children that still need to be addressed. Thus, the types of activities that allow the use of child labor are insufficiently regulated, there is no definition of the term "easy work for minors", ambiguous in national legislation is the definition of the age of employment for minors, work in which does not harm their health, morals and education. The author states that in general the Code of Labor Laws of Ukraine includes provisions on the work of minors, the articles of which comply with the norms adopted in Western countries regarding the possibility of involving minors of different ages in work of different weights, the responsibility of the employer concluding an employment contract. ensuring optimal working conditions for a minor. In addition, we would like to add that due to the rapid technological development, today there is a real possibility of reducing the working age of children. For example, it would be appropriate to involve children in work in the field of information technology and so on. Thus, in connection with the above, we consider it necessary to update the labor legislation in the context of juvenile labor, namely to reduce the age at which children can work, at least up to 14 years. Keywords: minors, work of minors, labor benefits for minors, minors, protection of labor rights of minors.

$\Pi$ остановка проблеми. Розробка єдиного механізму правового регулювання трудових відносин повинна проходити шляхом приведення його у відповідність до норм Конституції України [1], а також із врахуванням загальноприйнятих міжнародних норм і принципів. Не менш важливим для українського суспільства є приведення у дію окремих норм трудового права, які існують лише "де юре», а "де фракто» залишаються дієвими лише на папері. Не виключенням $є$ і зазначене законодавцем у трудовому кодексі України право на забезпечення працею осіб, які не досягли 18 річного віку. Так, чимало неповнолітніх осіб, серед яких студенти та школярі, намагаються заробити власні кошти шляхом пошуку різного роду підробіток. Тим більше проблематика правового регулювання праці неповнолітніх актуалізуеться напередодні Міжнародного дня праці, який відзначатиметься в нашій державі 28 квітня 2021 року [2].

Не дивлячись на те, що вітчизняний законодавець чітко встановив вимоги щодо прийняття неповнолітніх на роботу, а також права неповнолітніх працівників, роботодавці обходять правові положення і порушують встановлені заборони. Питання забезпечення зайнятості молоді є важливим для суспільства і держави, тому визначає 
особливі завдання для правового регулювання в цій сорері. Ігнорування вказаної проблеми може призвести до відсутності кваліфрікаційного кадрового потенціалу в країні, підвищення рівня незайнятості, злочинності серед молоді.

Аналіз останніх досліджень. Питанням дослідження та вивчення окремих аспектів правового регулювання та охорони праці неповнолітніх займалися різні науковці, у тому числі: В.Б. Бачук, О.В. Боков, Т.В. Дереза, М.А. Дубас, С. Душко, С.Д. Іріоглу, О.М. Корнева, Н.С. Пузирна, Ю.Г. Семигін, А.С. Сидоренко, О.А. Ситницька, I.В. Хохрякова, В.В. Юровська та ін. наукові здобутки які стали базисними для написання цієї наукової статті.

Виділення невирішених раніше частин загальної проблеми. Однак, більша частина науковців у своїх працях акцентуе увагу на загальних засадах правового регулювання праці неповнолітніх. В свою чергу, дослідження міжнародного правового регулювання праці неповнолітніх дозволить запозичити позитивний зарубіжний досвід у національну правову систему, дозволить гармонізувати внутрішне законодавство із європейськими стандартами та вимогами.

Мета статті. Головною метою цієї роботи є наведені вище обставини, які у своїй сукупності обумовлюють необхідність і своєчасність дослідження зазначеної проблематики, що визначають ії актуальність, наукову, теоретичну та практичну значущість й зумовили вибір теми ціеї наукової статті.

Виклад основного матеріалу. У ст. 43 Конституції України проголошено право кожного громадянина на працю, яке передбачає можливість заробляти собі на життя роботою, яку він вільно обирає або на яку вільно погоджуеться [1]. Так, значна кількість підлітків (школярі, студенти) реалізовують своє право на працю з метою отримання додаткового заробітку, особливо у період канікул, у вільний від навчання час, а у деяких випадках - у час свого навчання. Роботодавці частіше за все користуються такою ситуацією і нівелюють правами неповнолітніх осіб, залучаючи їх до виконання робіт навіть під час навчання. Так, згідно зі ст. 187 Кодексу законів про працю України (далі - КЗПП України), неповнолітні, тобто особи, що не досягли вісімнадцяти років, у трудових правовідносинах прирівнюються у правах до повнолітніх [3], однак володіють багатьма пільгами, як наприклад, у серері охорони праці, робочого часу, відпусток та деяких інших умов праці, визначених законодавством України.

Враховуючи розвиток вітчизняної економіки, появи нових форм господарювання та поширення безробіття, в нашій державі проблеми трудової діяльності неповнолітніх є одними з найактуальніших. Нині має місце численні порушення трудового законодавства, недотримання прав працівників, зокрема неповнолітніх.

Слід визначити, який вік особи у чинному законодавстві визначається як неповнолітній. Так, у ст. 6 Сімейного кодексу України встановлено, що «неповнолітньою вважається дитина у віці від чотирнадцяти до вісімнадцяти років» [4]. Такої ж позиції дотримано і у Цивільному кодексі України, де у ч. 1 с. 32 зазначено вік особи, яка $є$ неповнолітньою (від 14 до 18 років) [5].

В свою чергу, у ст. 7 Конвенції Міжнародної Організації Пращі «Про мінімальний вік для прийому на роботу» визначено, що прийом на роботу осіб, які досягли 14-річного віку допускається за наявності таких умов: а) ці особи повинні бути учнями загальноосвітніх шкіл чи інших навчальних закладів відповідної класифрікації; б) виконувана робота має бути легкою і не завдати шкоди здоров'ю чи розвитку; в) робота не повинна завдавати шкоди відвідуваності навчального закладу, порушувати навчальний процес, має виконуватися у вільний від навчання час; г) отримано згоду одного з батьків або особи, яка його змінюе [6]. Такі положення, що закріплені у міжнародних документах створюють підпрунтя для національного законодавства країн, ці норми виступають правовими гарантіями захисту трудових прав неповнолітніх із врахуванням їх потреб у навчанні, особистому розвитку, здоров ї тощо.

Також цікаво зауважити, що у нормах Європейської соціальної хартії, а саме у ст. 7 встановлено мінімальний вік прийняття на роботу неповнолітнього, що становить 15 років, за винятком дітей, які залучаються до виконання робіт, визнаних легкими роботами, які не завдають шкоди здоров'ю дітей, їхній моралі або освіті [7]. Крім того, у цьму міжнародному акті встановлені і заборони щодо робіт неповнолітніх, а саме дитині заборонено працювати із умовами праці, які визнані небезпечними і шкідливими для здоров'я; заборонено працювати, якщо внаслідок цьог порушується процес повного навчання дитини, яка здобуває обов'язкову освіту; заборонено працювати із порушенням тривалості робочого часу.

Щодо норм національного законодавства, то у Законі України «Про сприяння соціальному становленню та розвитку молоді в Україні» від 05.02.1993 р. № 2998-XII визначено, що молодь це молоді громадяни України віком від 14 до 35 років та неповнолітніми вважаються особи до 18 років, але відсутне визначення мінімального віку початку трудової діяльності [8]. Знов ж таки, слід зауважити, що такі норми є застарілими та потребують оновлення, ці законодавчі положення мають ще радянський характер та не відповідають сучасним умовам господарювання.

В нашій державі все ще діє КзпП, що був прийнятий у 1971 році, цей кодекс змінений та доопрацьований, він встановлюе особливості правового регулювання працевлаштування неповнолітніх. Так, згідно зі ст. 188 КЗпП не допускається прийняття на роботу осіб молодше 16 років. Як виняток, за згодою одного із батьків або особи, що його замінюе, можуть прийматись на роботу особи, які досягли 15 років. Крім того, для підготовки молоді до продуктивної праці допускається прийняття на роботу учнів загальноосвітніх шкіл, профресійно-технічних і середніх спеціальних навчальних закладів для виконання легкої роботи, що не завдає шкоди здоров'ю і не порушує процесу навчання, у вільний від навчання час по досягненні ними чотирнадцятирічного віку за згодою одного з батьків або особи, що його замінює [3].

Так, зазначаючи у законодавчих положеннях щодо залучення неповнолітнього працівника лише до легкої роботи, законодавець, враховує психофрізіологічні особливості організму неповнолітнього, захищає його від виробничих шкідливостей. Для џього у КЗпП України передбачено спеціальні норми, які в комплексі створюють особливу охорону праці неповнолітніх працівників. Наприклад, частина перша статті 190 КЗпП, передбачає, що забороняється застосування праці 
осіб молодше вісімнадцяти років на важких роботах і на роботах 3 шкідливими або небезпечними умовами пращі, а також на підземних роботах.

При прийнятті на роботу неповнолітньої особи необхідно пам'ятати, що такій особі має виповнитись щонайменше 16 років, в іншому випадку вимагається обгрунтувати необхідність прийняття такої особи на роботу та до особової справи працівника долучити: 1) копію свідоцтва про народження (за відсутності паспорта громадянина України); 2) згоду одного з батьків або особи, що його замінюе - якщо особі від 14 до 16 років; 3) документ, який підтверджує, що особа буде виконувати роботу у вільний від навчання час - якщо особі від 14 до 15 років; 4) медичну довідку [9].

Разом із тим, станом на сьогодення у нащіональній правовій системі має місце низка проблемних питань в сфрері трудової зайнятості дітей, які ще потребують вирішення. Так, у трудовому законодавстві недостатньо чітко регламентовано види діяльності, де дозволяється використовувати працю дітей, відсутне законодавча дефініція "легка робота для неповнолітніх», має місце неоднозначність щодо визначення мінімального віку початку трудової діяльності для неповнолітніх, робота в якому не наносить шкоди їх здоров'ю, моралі та освіті [10]. У зв’язку з наведеним існує нагальна потреба щодо вдосконалення чинного трудового законодавства та актуалізується питання щодо вивчення позитивного міжнародного досвіду охорони праці неповнолітніх.

У більшості країн світу відносно трудового договору неповнолітні ототожнюються 3 дорослим штатом працюючих. Проте у сфері охорони трудової діяльності, відпусток та робочих годин для них існують пільги, що регулюються законодавчими важелями різних країн. Охорона праці неповнолітніх займає особливе місце у міжнародно-правовому регулюванні, їй присвячено багато конвенцій та рекомендацій МОП. В залежності від країни існують різні вікові обмеження, які залежать від виду діяльності [11]. Цікаво зауважити, що мінімальний вік для початку трудової діяльності в Сгипті - це 12 років, а, наприклад, у Філіппінах - 14, а в Гонконзі вже 15 . У деяких країнах має місце диференційований підхід до встановлення мінімального віку трудової діяльності. Так, у Перу в сорері сільського господарства встановлено мінімальний вік 14 років, в промисловості - 15; в глибоководному риболовецькому промислі - 16, а для роботи в портах і в морі - 18. Такий підхід дозволяє на законодавчому рівні закріпити відмінність між легкими і небезпечними видами роботами, де для виконання легких робіт слід досягнути 12 років, а вже для виконання небезпечних робіт встановлюється вік від 16 до 18 років [12].

Щодо досвіду європейських країн, то, наприклад, у Франції у Трудовому кодексі встановлено заборона щодо пращі дітей до закінчення ними навчання в школі та досягнення ними шістнадцяти років. Виключення становлять випадки праці дітей під час шкільних канікул та за умови досягнення чотирнадцяти років [13]. Подібні вікові обмеження та правові гарантії для неповнолітніх встановлено у німещкому законодавстві. Так, за Конституціею Німеччини забороняеться використовувати працю осіб, молодших тринадцяти років. Ценз для отримання постійної роботи за німецьким правом становить п’ятнадцять років, знов ж таки якщо дити- на ще навчається, то така робота має бути надана у вільний від навчання час, що становить не білыше ніж 3 години на день. Для неповнолітніх у віці від 15 до 18 років встановлено трудові гарантії тривалості робочого часу (не більше ніж 40 годин на тиждень і 8 годин на день) гарантії відпустки та гарантії щодо обгрунтованого звільнення [14]. Можна зауважити, що в цілому такі положення мають відображення і в нащіональному законодавстві, що свідчить про проголошений нашою держави євроінтеграційний вектор свого розвитку.

За національним законодавством Польщі установлено заборону приймати на роботу осіб до 16 років. Також закріплено, що обов'язковим для початку трудової діяльності $є$ закінчення гімназії, наявність медичного висновку, який підтверджує, що робота цього виду не загрожуватиме стану здоров'я такої особи [15]. Такий підхід є виваженим, проте вважаємо, що враховуючи сучасні реалії доцільно знизити віковий ценз для початку трудової діяльності.

Дуже цікавий досвід має така країна, як Естонія, де праця дітей є чітко регламентованою та закони передбачають суворі обмеження та правила, що стосуються прийняття на роботу молоді. Так, за естонським трудовим законодавством, роботодавещ не може укладати трудовий договір із неповнолітніми у віщі до 15 років. Винятком $є$ роботи, де передбачені прості обов'язки й робота не потребує фрізичних чи розумових навантажень, вік прийняття на такі роботи становить 13-14 років. Також передбачена можливість працювати дитині вже 37 років: неповнолітньому віком від 7 до 12 років дозволяеться виконувати незначну роботу у сфрері культурної, художньої, спортивної й рекламної діяльності. Гарантією праці неповнолітніх є дотримання робочого часу, а саме особи віком від 7 до 12 років можуть працювати 2 години на добу й 12 годин протягом 7-денного періоду навчання, після школи особам дозволять працювати 3 години на добу й 15 годин на тиждень; для осіб 13-14 років тривалість робочого часу становить 2 години на день і 12 годин на тиждень у період навчання й після навчання - 7 годин на день і 35 годин на тиждень. Для осіб, які досягли 15-річного віку, тривалість робочого дня становить 8 годин, а робочого тижня - 40 годин [16-17]. Важливо додати, що правове регулювання праці неповнолітніх здійснюеться законом про трудовий договір.

У країнах англо-американської системи права (Великобританія, Австралія, США і Канада) також встановлені спеціальні норми щодо правового регулювання праці неповнолітніх. Так, неповнолітнім заборонено працювати під час навчання у школі, встановлено гарантії трудового часу (дозволено працювати не більше трьох годин в звичайний навчальний день та 18 годин на тиждень; у вихідні та під час канікул - не більше 8 годин на день та не більше 40 годин на тиждень. Також встановлено заборону щодо нічної роботи: у законодавстві цих країн встановлено початок робочої зміни не раніше сьомої години ранку та її завершення не пізніше 19 години.

У пострадянських країнах, таких як Білорусь та Росія також є спеціальне законодавство, що регулює пращю неповнолітніх. Неповнолітнім, так само як і в нашій державі, встановлюються особливі трудові пільги та гарантії, що обумовлено їх недостатнім життевим досвідом, розвитком 
їх фрізичного здоров’ я, необхідністю ще продовжувати навчання тощо [10].

Висновки i пропозиції. На сьогоднішній день, КЗпП України включає положення про працю неповнолітніх, статті якого відповідають нормам, прийнятим в західних країнах, стосовно можливості залучення неповнолітніх різного віку до праці різних типів важкості, відповідальності роботодавця, який заключає трудовий договір 3 неповнолітнім, та забезпечення оптималь- них умов пращі для неповнолітнього. Крім того, хочемо додати, що у зв'язку зі стрімким технологічним розвитком, сьогодні існує реальна можливість зниження трудового віку дітей. Наприклад, слушним було б залучати дітей до праці у сфрері індормаційних технологій тощо. Так, у зв'язку із вказаним, вважаємо за необхідне оновлення трудового законодавства у контексті праці неповнолітніх, а саме щодо зниження віку, з якого можуть працювати діти, хоча б до 14 років.

\section{Список літератури:}

1. Конституція України від 28.06.1996 № 254к/96-BP. URL: https://zakon.rada.gov.ua/rada/show/254\%D0\%BA/ $96-\% \mathrm{D} 0 \% \mathrm{~B} 2 \% \mathrm{D} 1 \% 80$

2. День праці в Україні відзначатиметься 28 квітня 2021 року. URL: https://minjust.gov.ua/news/info/ vidznachennya-dnya-ohoroni-pratsi-u-2021-rotsi

3. Кодекс законів про працю : Закон України від 10.12.1971 № 322-VIII. URL: https://zakon.rada.gov.ua/laws/main/322-08

4. Сімейний кодекс України : Закон України від 10.01.2002 № 2947-III. URL: https://zakon.rada.gov.ua/laws/ show/2947-14/ed20120408

5. Цивільний кодекс України : Закон України від 16.01.2003 № 435-IV. URL: https://zakon.rada.gov.ua/laws/ show/435-15/paran161

6. Про мінімальний вік для прийому на роботу : Конвенція Міжнародної організації праці від 26 червня 1973 року № 138. URL: https://zakon.rada.gov.ua/laws/show/993_054/card5

7. Європейська соціальна хартія (переглянута). URL: http://zakon5.rada.gov.ua/laws/show/994_062

8. Про сприяння соціальному становленню та розвитку молоді в Україні : Закон України від 5 лютого 1993 року N 2998-XII. URL: http://zakon3.rada.gov.ua/laws/show/2998-12

9. Особливості правового регулювання праці неповнолітніх. URL: http://kr.dsp.gov.ua/index.php/2463-kr290517

10. Боков О.В. Правові питання регулювання праці неповнолітніх в Україні (в контексті адаптації національного законодавства до міжнародної правової бази країн Європейського союзу). Державно-управлінські студіï. 2017. № 2. C. 15-21.

11. Корнева O.М., Дереза М.А. Порівняльний аналіз охорони праці неповнолітніх в Україні та інших країнах світу. URL: http://webcache.googleusercontent.com/search?q=cache:IfQRANA9e_YJ:confopcb.iee.kpi.ua/proc/ article/download/143761/141625+\&cd=1\&hl=ru\&ct=clnk\&gl=ua

12. Васильева Н.В., Щеглова С.Н. Подросток и работа: как уберечь себя от эксплуатации. Москва : Социум, 2001. $30 \mathrm{c}$.

13. French Labour Code. URL: www.d2rqfo7jzwsuwpcloudfront.net/wp-content/upeacas/2016/09/Labour=Code= Franch_final.pdf

14. Basic Law for the Federal Republic of Germany, 23 May 1949 (Last amended on 13 July 2017). URL: www.ltg_lestellservice.de/pdf/80201000.pdf

15. Polish Labour Code, 1997. URL: www.en.pollub.pl/files/17/atachment/98_Polish-Labour-Code,1997.pdf

16. Employment Contracts Act Republic of Estonia, 2009. URL: www.riigiteoctaga.ee/en/eli/520062016009/cosolide

17. Сидоренко А.С. Особливості праці неповнолітніх: міжнародний досвід. Вчені записки ТНУ ілені В.I. Вернадського. 2020. № 3. С. 86-90.

\section{References:}

1. Konstytutsiia Ukrainy vid 28.06.1996 № 254k/96-VR. URL: https://zakon.rada.gov.ua/rada/show/254\%D0\%BA/ $96-\% \mathrm{D} 0 \% \mathrm{~B} 2 \% \mathrm{D} 1 \% 80$

2. Den pratsi v Ukraini vidznachatymetsia 28 kvitnia 2021 roku. URL: https://minjust.gov.ua/news/info/ vidznachennya-dnya-ohoroni-pratsi-u-2021-rotsi

3. Kodeks zakoniv pro pratsiu: Zakon Ukrainy vid 10.12.1971 № 322-VIII. URL: https://zakon.rada.gov.ua/laws/main/322-08

4. Simeinyi kodeks Ukrainy: Zakon Ukrainy vid 10.01.2002 № 2947-III. URL: https://zakon.rada.gov.ua/laws/ show/2947-14/ed20120408

5. Tsyvilnyi kodeks Ukrainy: Zakon Ukrainy vid 16.01.2003 № 435-IV. URL: https://zakon.rada.gov.ua/laws/ show/435-15/paran161

6. Pro minimalnyi vik dlia pryiomu na robotu: Konventsiia Mizhnarodnoi orhanizatsii pratsi vid 26 chervnia 1973 roku № 138. URL: https://zakon.rada.gov.ua/laws/show/993_054/card5

7. Yevropeiska sotsialna khartiia (perehlianuta). URL: http://zakon̄̄.rada.gov.ua/laws/show/994_062

8. Pro spryiannia sotsialnomu stanovlenniu ta rozvytku molodi v Ukraini: Zakon Ukrainy vid 5 liutoho $1993 \mathrm{roku}$ № 2998-XII. URL: http://zakon3.rada.gov.ua/laws/show/2998-12

9. Osoblyvosti pravovoho rehuliuvannia pratsi nepovnolitnikh. URL: http://kr.dsp.gov.ua/index.php/2463-kr290517

10. Bokov O.V. (2017) Pravovi pytannia rehuliuvannia pratsi nepovnolitnikh v Ukraini (v konteksti adaptatsii natsionalnoho zakonodavstva do mizhnarodnoi pravovoi bazy krain Yevropeiskoho soiuzu). Derzhavno-upravlinski studii, no. 2, pp. 15-21.

11. Kornieva O.M., Dereza M.A. Porivnialnyi analiz okhorony pratsi nepovnolitnikh v Ukraini ta inshykh krainakh svitu URL: http://webcache.googleusercontent.com/search?q=cache:IfQRANA9e_YJ:confopcb.iee.kpi.ua/proc/article/ download/143761/141625+\&cd=1\&hl=ru\&ct=clnk\&gl=ua

12. Vasyleva N.V., Shchehlova S.N. (2001) Podrostok y rabota: kak uberech sebia ot ekspluatatsyy. Moscow: Sotsyum, 30 p.

13. French Labour Code. URL: www.d2rqfo7jzwsuwpcloudfront.net/wp-content/upeacas/2016/09/Labour=Code= Franch_final.pdf

14. Basic Law for the Federal Republic of Germany, 23 May 1949 (Last amended on 13 July 2017). URL: www.ltg_lestellservice.de/pdf/80201000.pdf

15. Polish Labour Code, 1997. URL: www.en.pollub.pl/files/17/atachment/98_Polish-Labour-Code,1997.pdf

16. Employment Contracts Act Republic of Estonia, 2009. URL: www.riigiteoctaga.ee/en/eli/520062016009/cosolide

17. Sydorenko A.S. (2020) Osoblyvosti pratsi nepovnolitnikh: mizhnarodnyi dosvid. Vcheni zapysky TNU imeni V.I. Vernadskoho, no. 3, pp. 86-90. 